\title{
Short-Term Air Quality Gains of COVID-19 Pandemic Lockdown of Port Harcourt, Nigeria
}

\author{
Adewale Jonathan Adeyemi ${ }^{1}$, Rogers Bariture Kanee ${ }^{1}$, \\ David Onojiede Edokpa ${ }^{2}$, Precious Nwobidi Ede ${ }^{2}$ \\ ${ }^{1}$ Institute of Geoscience and Space Technology, Rivers State University, Port Harcourt, Nigeria \\ ${ }^{2}$ Department of Geography and Environmental Management, Rivers State University, Port Harcourt, Nigeria \\ Email: *onojiede@gmail.com
}

How to cite this paper: Adeyemi, A. J., Kanee, R. B., Edokpa, D. O., \& Ede, P. N. (2021). Short-Term Air Quality Gains of COVID-19 Pandemic Lockdown of Port Harcourt, Nigeria. Journal of Geoscience and Environment Protection, 9, 110-123. https://doi.org/10.4236/gep.2021.92007

Received: September 22, 2020

Accepted: February 17, 2021

Published: February 20, 2021

Copyright $\odot 2021$ by author(s) and Scientific Research Publishing Inc. This work is licensed under the Creative Commons Attribution International License (CC BY 4.0).

http://creativecommons.org/licenses/by/4.0/

\begin{abstract}
The air quality index (AQI) of a location informs how clean or unhealthy the ambient air is. While COVID-19 pandemic on one hand threatened the health of mankind globally, on the other hand was a respite to poor air quality of most cities. This study evaluated the positive effects of the brief COVID-19 lockdown on the air quality of Port Harcourt city, Nigeria. Air quality parameters aimed at assessing air quality index of Port Harcourt Metropolis before, during and after COVID-19 pandemic lockdown were monitored and compared. Data were analysed and AQI of sampled locations computed using the US EPA recommended standard procedure. Results from the study showed that, the ambient air quality of Port Harcourt was hazardous for breathing before lockdown. During shutdown of activities, the air quality improved to unhealthy status, with an average reduction AQI of 261.7 points. However, an average increase of 100.7 points, resulting to very unhealthy air status for residents after lockdown was observed. The unhealthy status during lockdown shows that anthropogenic activities were still on despite the Pandemic shutdown of economic activities. Also, decrease in levels of the criteria air pollutants was observed. Before lock down, the range levels of $\mathrm{SO}_{3}, \mathrm{NO}_{2}$, $\mathrm{CO}, \mathrm{O}_{3}, \mathrm{PM}_{2.5}$ and $\mathrm{PM}_{10}$ were $<0.1-1.2 \mathrm{ppm},<0.1-0.1 \mathrm{ppm}, 8-28 \mathrm{ppm},<0.1$ ppm, $20-140 \mu \mathrm{g} / \mathrm{m}^{3}, 15-135 \mu \mathrm{g} / \mathrm{m}^{3}$, respectively. In the period of lockdown, the levels reduced considerably, especially $\mathrm{CO}$ and $\mathrm{PM}_{2.5}$ and $\mathrm{PM}_{10}(1-12$ $\mathrm{ppm}, 5-60 \mu \mathrm{g} / \mathrm{m}^{3}$, and $10-50 \mu \mathrm{g} / \mathrm{m}^{3}$ ). Conversely, after lockdown, there was upsurge in levels of the pollutants, especially $\mathrm{CO}$ and $\mathrm{PM}_{2.5}$ and $\mathrm{PM}_{10}(4-16$ $\left.\mathrm{ppm}, 10-110 \mu \mathrm{g} / \mathrm{m}^{3}, 10-90 \mu \mathrm{g} / \mathrm{m}^{3}\right)$. Authorities are expected to establish routine air quality measurements stations and communicate daily air quality to residents, for public health precaution purposes. Shutdown of industrial activities instituted by Government in curtailing the surge of COVID-19 pandemic could likely be a novel environmental model for mitigating air
\end{abstract}


pollution in highly hazardous air pollution emergency domains.

\section{Keywords}

Air Quality Index, Air Pollution, COVID-19 Pandemic, Lockdown, Port Harcourt

\section{Introduction}

Coronavirus disease 2019 (COVID-19) is a highly infectious and communicable disease caused by the recently discovered coronavirus, which arose from severe acute respiratory syndrome coronavirus 2 (SARS-COV-2) infection (WHO, 2020; Zhou et al., 2020). With the outbreak observed in December 2019 in Wuhan, China and WHO declaring it a pandemic on 11 March 2020 (WHO, 2020), diverse public health emergency measures were invoked. As the number of deaths and infections continued to increase across the world, national, sub-national and city level governments introduced stringent non-pharmaceutical measures such as economic lockdown, travel restrictions and bans, social distancing, shutdown of schools and public activities, isolation, and quarantine as effective response in curbing the spread of the disease (Anderson et al., 2020; Gatto et al., 2020; Gourinchas, 2020; Tobías, 2020; UNESCO, 2020). The lockdown of cities halted industrial and almost all other human economic and social activities (Wang et al., 2020; Bao \& Zhang, 2020; Cristina et al., 2020). This study applied the tool of air quality indexing to establish how the restrictive measures that accompanied COVID-19 Pandemic impacted the air quality of Port Harcourt, Nigeria.

The air quality index (AQI) of a location shows the daily air quality and tells how clean or unhealthy the ambient air is, with associated public health concern after breathing unhealthy air (US EPA, 2014). While the trend in morbidity and mortality of COVID-19 continued to rise in most of 2020, the environment was observed to be recovering from long-term air pollution levels (Cristina et al., 2020; Paital, 2020; Arora et al., 2020; Mahato et al., 2020; Yuri et al., 2020). Unlike cities such as Abuja (Kanee et al., 2020a), long before the lockdown of Port Harcourt, residents have been experiencing particulate matter deposits in the form of soot haze on surfaces and black stains in nasal orifices with increasing trends of cardiopulmonary disease and deaths documented (Ede \& Edokpa, 2017; Edokpa \& Ede, 2019; Yakubu, 2017; Fienemika et al., 2018; RSMENV, 2019; Kanee et al., 2020b).

Air pollution is said to result from diverse sources including petroleum refining and gas flaring, vehicular and traffic emissions, heavy duty and industrial machines incomplete combustions, open waste burnings, biomass, etc. (Augustine, 2012; Ladan, 2013; Taiwo, 2016; Abowei \& Tawari, 2012; Guo et al., 2018; Chen et al., 2017; Fu \& Gu, 2017; RSMENV, 2019). Adverse effects on human health 
have been strongly associated with poor air quality especially among vulnerable population like children and population in petroleum industrial ecology (Mudu, Terracini, \& Martuzzi, 2014; Maduka \& Tobin-West, 2017; Fienemika et al., 2018; Oliveira, Slezakova et al., 2019; Broekstra et al., 2019). During the lockdown, some anthropogenic activities known to generate pollution were suspended which could be responsible for observed decline in ambient air pollution across cities all over (Bao \& Zhang, 2020; Asumadu et al., 2020).

Studies have established a link between higher concentrations of air pollutants and higher risk of COVID-19 infection (Zhou et al., 2020), and this may possibly explain the high number of COVID-19 infection in Port Harcourt relative to other cities in Nigeria. With recorded air quality gains from the lockdown of cities however, mortality from non-communicable disease associated with ambient air pollution in petroleum industrial places have been demonstrated to decline significantly by Gautam (2020). To provide evidence-based data for environmental and public health policies towards the attainment of default clean, healthy and air pollution free environment, the context of pandemic lockdown provides a rare opportunity to assess the effects of industrial and other anthropogenic related activities on air quality of Port Harcourt metropolis. In this study, air quality data before, during and after lockdown were sampled across selected locations of Port Harcourt metropolis and complemented with satellite data and findings extrapolated for possible gains on air quality and the health of residents.

\section{Materials and Methods}

\subsection{Study Design}

Routine measurements of air quality parameters across Port Harcourt before, during and after the lockdown of the city were carried out. The measurements were fitted into an air quality index tool in order to establish trends in the healthiness of the city's atmosphere.

\subsection{Sampling}

Sampling locations were chosen based on a randomised approach. Activity types were however factored into the process because Port Harcourt is a sprawling landscape of over 2.5 million inhabitants. It straddles a core urban area and a conurbation of adjoining towns like Nchia, Oyigbo and Okrika, within which are industrial and commercial layouts; low and high residential areas. The borders of the study area are also surrounded by the activities of artisan refineries which generates black carbon emissions locally known as "soot" that infiltrate the boundary layer atmosphere of Port Harcourt. Sampling sites established before the lockdown were leveraged although research team's level of access into some neighbourhoods in view of imposed movement restrictions during the lockdown was sometimes challenging. Figure 1 shows the sampled locations across Port Harcourt metropolis. 


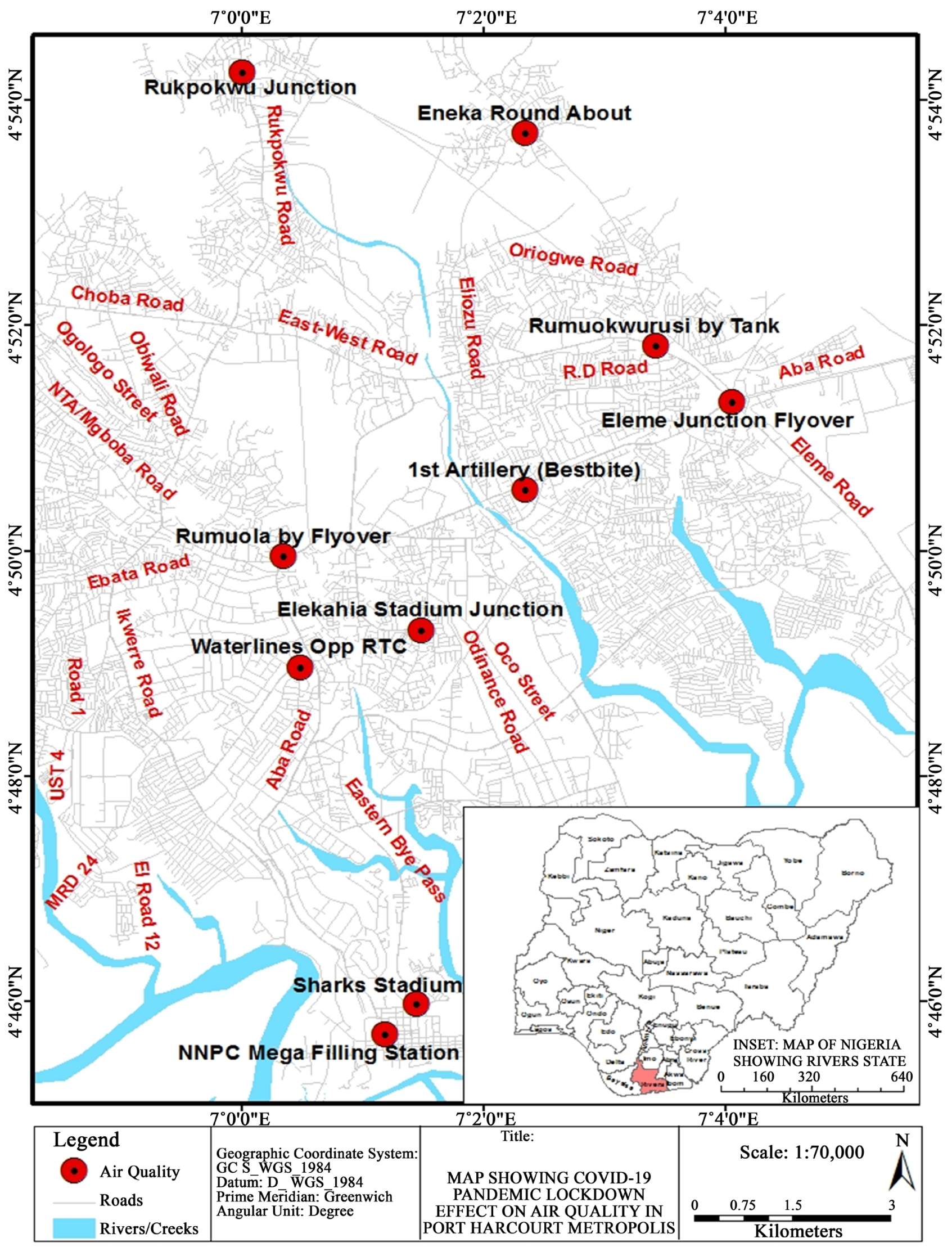

Figure 1. Port Harcourt Metropolis. 


\subsection{Data Collection}

The measurement values before lockdown (BL) were obtained from an earlier conducted exercise in March, 2020. Air quality parameters during lockdown (DL) was recorded from $18^{\text {th }}$ to $20^{\text {th }}$ of May, 2020 and assessment after (AL) lockdown (post-movement restriction) was conducted between $2^{\text {nd }}$ to $5^{\text {th }}$ June 2020. The three sets of measurements (BL, DL and $\mathrm{AL}$ ) were conducted within 12:00 and 15:00 hours. Additionally, satellite data was retrieved via a satellite remote sensing application through a System for Integrated Modelling of Atmospheric Composition (SILAM). SILAM is a global-to-meso-scale dispersion model established for atmospheric composition, air quality, and emergency decision support applications, as well as for inverse dispersion problem solution. The model incorporates both Eulerian and Lagrangian transport routines, 8 chemico-physical transformation modules (basic acid chemistry and secondary aerosol formation, ozone formation in the troposphere and the stratosphere, radioactive decay, aerosol dynamics in the air, pollen transformations), 3- and 4-dimensional variational data assimilation modules. The obtained air quality dataset is made available on a $1500 \times 751$ latitude-longitude grid at a resolution of $0.24 \times 0.24$ degrees, which corresponds to about $25 \mathrm{~km}$ resolution.

A hand held instrument, EGVOC-180, was used for measuring the particulates in the ambient air by optical method. The criteria pollutants like sulphur dioxide $\left(\mathrm{SO}_{2}\right)$, nitrogen dioxide $\left(\mathrm{NO}_{2}\right)$ and carbon monoxide $(\mathrm{CO})$ were measured using a digital direct reading BOSEAN-BH-4S (Model: 1902314 \& 19028499) portable multi gas detector which detects gases continuously with high-sensitivity sensor. A GARMIN OREGON 550T GPS Receiver instrument configured in the Nigerian Mina datum with the geodetic co-ordinates of the points already imputed into the system was used to georeferenced the sampling stations. In the navigation mode, the equipment provided a compass of the targeted position, elevation above sea level and the UTM Coordinates of this target position.

\subsection{Data Analysis}

The AQI for the pollutants were evaluated following a standard formula developed by the United States Environmental Protection Agency as shown in Equation (1) (US EPA, 2014).

$$
I_{p}=\frac{I_{H i}-I_{L o}}{B P_{H i}-B P_{L o}}\left(C_{P}-B P_{L o}\right)+I_{L o}
$$

Where:

$I_{P}=$ the index for pollutant $P$;

$C_{P}=$ the rounded concentration of pollutant $P$;

$B P_{H i}=$ the breakpoint that is greater than or equal to $C_{P}$ :

$B P_{L o}=$ the breakpoint that is less than or equal to $C_{p}$;

$I_{H i}=$ the AQI value corresponding to $B P_{H i}$ and;

$I_{L o}=$ the AQI value corresponding to $B P_{L o}$. 
Table 1. US EPA breakpoint and air quality index.

\begin{tabular}{|c|c|c|c|c|c|c|}
\hline $\begin{array}{c}\mathrm{PM}_{10} \\
\left(\mu \mathrm{g} / \mathrm{m}^{3}\right)\end{array}$ & $\begin{array}{c}\mathrm{PM}_{2.5} \\
\left(\mu \mathrm{g} / \mathrm{m}^{3}\right)\end{array}$ & $\begin{array}{c}\mathrm{CO} \\
(\mathrm{ppm})\end{array}$ & $\begin{array}{c}\mathrm{SO}_{2} \\
(\mathrm{ppm})\end{array}$ & $\begin{array}{c}\mathrm{NO}_{2} \\
(\mathrm{ppm})\end{array}$ & AQI & $\begin{array}{c}\text { Level of } \\
\text { Health Concern }\end{array}$ \\
\hline $0-54$ & $0.0-15.4$ & $0.0-4.4$ & $0.000-0.034$ & - & $0-50$ & Good \\
\hline $55-154$ & $15.5-40.4$ & $4.5-9.4$ & $0.035-0.144$ & - & $51-100$ & Moderate \\
\hline $155-254$ & $40.5-65.4$ & $9.5-12.4$ & $0.145-0.224$ & - & $101-150$ & $\begin{array}{l}\text { Unhealthy for } \\
\text { sensitive group }\end{array}$ \\
\hline $255-354$ & $65.5-150.4$ & $12.5-15.4$ & $0.225-0.304$ & - & $151-200$ & Unhealthy \\
\hline $355-424$ & $150.5-250.4$ & $15.5-30.4$ & $0.305-0.604$ & $0.65-1.24$ & $201-300$ & Very unhealthy \\
\hline $425-504$ & $250.5-350.4$ & $30.5-40.4$ & $0.605-0.804$ & $1.25-1.64$ & $301-400$ & Hazardous \\
\hline $505-604$ & $350.4-500.4$ & $40.5-50.4$ & $0.805-1.004$ & $1.65-2.04$ & $401-500$ & Hazardous \\
\hline
\end{tabular}

The Equation (1) was utilised based on the pollutants concentrations data and breakpoints shown in Table 1. It is shown that the AQI is divided into six classes with definite colour codes and boundaries: Good (0 - 50), Normal (51 - 100), Unhealthy for sensitive groups (101 - 150), Unhealthy (151 - 200), Very unhealthy $(201-300)$ and Hazardous (>300). To estimate the AQI, the field measurements values of the following pollutants namely, particulate matter $\left(\mathrm{PM}_{10}\right.$ and $\left.\mathrm{PM}_{2.5}\right)$, carbon monoxide (CO), sulphur dioxide $\left(\mathrm{SO}_{2}\right)$ and nitrogen dioxide $\left(\mathrm{NO}_{2}\right)$ were collated. However, the most important of the pollutants was the particulates with significant record values. Thereafter, the average value from each pollutant was converted into individual index based on breakpoint boundary as shown in Table 1. The AQI equation was computed and programmed in Microsoft excel software format for flexible computation and responsive graphical user interface configuration. The format was configured to take about 7 air pollutants input values.

\subsection{Quality Assurance}

The research was managed and administered according to strict Quality Assurance procedures under the control of specific procedures, which ensures that objectives and requirements are achieved. Research procedures conformed to International Standard of Quality Management System (ISO 9001:2018), Environmental Management System (ISO 140001:2018) and Occupational health and safety management systems (ISO 45001:2018).

\section{Result}

Study result presented in Table 2 showed the mean values of the air quality index parameters measured before, during and after lockdown. Table 3 showed the ranges of measured parameters, while Table 4 showed the BL, DL and AL computed AQI of each of the sampled locations and the respective AQI indicator. Using the sampled areas as representation, Table 2 also showed the average AQI of Port Harcourt metropolis BL, DL and AL. The computed index and indicators are compared with the EPA reference AQI indicator (Figure 2) 
Table 2. Results of air quality index parameters measured before (BL), during (DL) and after (AL) lockdown.

\begin{tabular}{|c|c|c|c|c|c|c|c|c|c|}
\hline Location & Time & $\begin{array}{c}\mathrm{SO}_{2} \\
(\mathrm{ppm})\end{array}$ & $\begin{array}{c}\mathrm{NO}_{2} \\
(\mathrm{ppm})\end{array}$ & $\begin{array}{c}\mathrm{CO} \\
(\mathrm{ppm})\end{array}$ & $\begin{array}{c}\mathrm{O}_{3} \\
(\mathrm{ppm})\end{array}$ & $\begin{array}{c}\mathrm{PM}_{2.5} \\
\left(\mu \mathrm{g} / \mathrm{m}^{3}\right)\end{array}$ & $\begin{array}{c}\mathrm{PM}_{10} \\
\left(\mu \mathrm{g} / \mathrm{m}^{3}\right)\end{array}$ & $\mathrm{AQI}$ & Colour Indicator \\
\hline \multirow{3}{*}{$\begin{array}{c}\text { Rumuola by Fly-over } \\
\text { N04 } 49^{\prime} 57.8^{\prime \prime} \\
\text { E007 } 00^{\prime} 20.7^{\prime \prime}\end{array}$} & $\mathrm{BL}$ & 0.8 & 0.1 & 18 & $<0.1$ & 95 & 80 & 462 & HAZ \\
\hline & $\mathrm{DL}$ & 0.1 & $<0.1$ & 1 & $<0.1$ & 18 & 15 & 161 & $\mathrm{UH}$ \\
\hline & $\mathrm{AL}$ & 0.2 & 0.1 & 9 & $<0.1$ & 60 & 40 & 234 & VUH \\
\hline \multirow{3}{*}{$\begin{array}{c}1^{\text {st }} \text { Artillery by (Best bite) } \\
\text { N04 } 50^{\prime} 38.7^{\prime \prime} \\
\text { E007 } 02^{\prime} 16.7^{\prime \prime}\end{array}$} & $\mathrm{BL}$ & 0.4 & 0.04 & 20 & $<0.1$ & 50 & 45 & 335 & HAZ \\
\hline & DL & 0.2 & $<0.1$ & 4 & $<0.1$ & 14 & 12 & 234 & VUH \\
\hline & $\mathrm{AL}$ & 0.2 & $<0.1$ & 10 & $<0.1$ & 30 & 20 & 234 & VUH \\
\hline \multirow{3}{*}{$\begin{array}{l}\text { Rumukrushi by Tank } \\
\text { N04 } 51^{\prime} 49.8^{\prime \prime} \\
\text { E007 } 03^{\prime} 25.0^{\prime \prime}\end{array}$} & $\mathrm{BL}$ & 0.7 & 0.2 & 24 & $<0.1$ & 125 & 120 & 429 & HAZ \\
\hline & $\mathrm{DL}$ & $<0.1$ & $<0.1$ & 6 & $<0.1$ & 25 & 18 & 163 & $\mathrm{UH}$ \\
\hline & $\mathrm{AL}$ & 0.2 & 0.1 & 12 & $<0.1$ & 40 & 30 & 243 & VUH \\
\hline \multirow{3}{*}{$\begin{array}{c}\text { Eneka Round-About } \\
\text { N04 } 53^{\prime} 43.1^{\prime \prime} \\
\text { E007 } 02^{\prime} 20.5^{\prime \prime}\end{array}$} & $\mathrm{BL}$ & 0.4 & 0.05 & 8 & $<0.1$ & 20 & 15 & 331 & HAZ \\
\hline & DL & $<0.1$ & $<0.1$ & 3 & $<0.1$ & 20 & 10 & 140 & UHSG \\
\hline & $\mathrm{AL}$ & 0.1 & 0.04 & 6 & $<0.1$ & 30 & 20 & 163 & $\mathrm{UH}$ \\
\hline \multirow{3}{*}{$\begin{array}{l}\text { Waterline opposite RTC } \\
\text { N04 } 48^{\prime} 58.5^{\prime \prime} \\
\text { E007 } 00^{\prime} 29.0^{\prime \prime}\end{array}$} & $\mathrm{BL}$ & 0.6 & 0.1 & 16 & $<0.1$ & 120 & 105 & 391 & HAZ \\
\hline & DL & $<0.1$ & $<0.1$ & 4 & $<0.1$ & 42 & 28 & 140 & UHSG \\
\hline & $\mathrm{AL}$ & 0.1 & 0.1 & 7 & $<0.1$ & 80 & 60 & 208 & VUH \\
\hline \multirow{3}{*}{$\begin{array}{l}\text { Elekahia Stadium Junction } \\
\text { NO4 } 49^{\circ} 19.91^{\prime \prime} \\
\text { E007 } 1^{\prime} 27.13^{\prime \prime}\end{array}$} & $\mathrm{BL}$ & 0.5 & 0.004 & 12 & $<0.1$ & 35 & 20 & 364 & HAZ \\
\hline & DL & $<0.1$ & $<0.1$ & 2 & $<0.1$ & 5 & 10 & 140 & UHSG \\
\hline & $\mathrm{AL}$ & 0.1 & $<0.1$ & 8 & $<0.1$ & 10 & 10 & 188 & $\mathrm{UH}$ \\
\hline \multirow{3}{*}{$\begin{array}{c}\text { Sharks Stadium } \\
\mathrm{NO}^{\circ} 45^{\prime} 55.55^{\prime \prime} \\
\mathrm{E} 007^{\circ} 1^{\prime} 19.5^{\prime \prime}\end{array}$} & $\mathrm{BL}$ & 0.7 & 0.02 & 10 & $<0.1$ & 40 & 35 & 429 & HAZ \\
\hline & DL & $<0.1$ & $<0.1$ & 3 & $<0.1$ & 15 & 10 & 140 & UHSG \\
\hline & $\mathrm{AL}$ & 0.4 & $<0.1$ & 4 & $<0.1$ & 30 & 20 & 331 & HAZ \\
\hline \multirow{3}{*}{$\begin{array}{l}\text { NNPC Mega Filling Station } \\
\mathrm{NO}^{\circ} 45^{\prime} 42.69^{\prime \prime} \\
\mathrm{E} 007^{\circ} 1^{\prime} 9.72^{\prime \prime}\end{array}$} & $\mathrm{BL}$ & 0.8 & 0.04 & 22 & $<0.1$ & 135 & 110 & 462 & HAZ \\
\hline & DL & 0.1 & $<0.1$ & 4 & $<0.1$ & 20 & 15 & 140 & UHSG \\
\hline & $\mathrm{AL}$ & 0.3 & 0.02 & 8 & $<0.1$ & 80 & 70 & 298 & VUH \\
\hline \multirow{3}{*}{$\begin{array}{l}\text { Eleme Junction Flyover } \\
\text { N04 } 53^{\prime} 43.1^{\prime \prime} \\
\text { E007 } 02^{\prime} 20.5^{\prime \prime}\end{array}$} & $\mathrm{BL}$ & 1.2 & 0.1 & 28 & $<0.1$ & 140 & 135 & 593 & HAZ \\
\hline & $\mathrm{DL}$ & 0.2 & $<0.1$ & 12 & $<0.1$ & 60 & 50 & 257 & VUH \\
\hline & $\mathrm{AL}$ & 0.6 & 0.05 & 16 & $<0.1$ & 110 & 90 & 391 & HAZ \\
\hline \multirow{3}{*}{$\begin{array}{l}\text { Rukpokwu Junction } \\
\text { N045' } 54^{\prime} 11.7^{\prime \prime} \\
\text { E006 } 59^{\prime} 19.0^{\prime \prime}\end{array}$} & $\mathrm{BL}$ & 0.9 & 0.02 & 14 & $<0.1$ & 50 & 45 & 495 & HAZ \\
\hline & $\mathrm{DL}$ & $<0.1$ & $<0.1$ & 5 & $<0.1$ & 15 & 15 & 159 & $\mathrm{UH}$ \\
\hline & $\mathrm{AL}$ & 0.2 & 0.01 & 8 & $<0.1$ & 20 & 18 & 391 & HAZ \\
\hline
\end{tabular}

\section{Key Index}

Hazardous (HAZ)

Unhealthy (UH)

Very Unhealthy (VUH)

Unhealthy for sensitive groups (UHSG) 
Table 3. Lower and upper limits of measured air quality parameter values.

\begin{tabular}{ccccccc}
\hline Timing & $\mathrm{SO}_{2}(\mathrm{ppm})$ & $\begin{array}{c}\mathrm{NO}_{2} \\
(\mathrm{ppm})\end{array}$ & $\mathrm{CO}(\mathrm{ppm})$ & $\begin{array}{c}\mathrm{O}_{3} \\
(\mathrm{ppm})\end{array}$ & $\begin{array}{c}\mathrm{PM}_{2.5} \\
\left(\mu \mathrm{g} / \mathrm{m}^{3}\right)\end{array}$ & $\begin{array}{c}\mathrm{PM}_{10} \\
\left(\mu \mathrm{g} / \mathrm{m}^{3}\right)\end{array}$ \\
\hline Before Lockdown (BL) & $<0.1-1.2$ & $<0.1-0.1$ & $8-28$ & $<0.1$ & $20-140$ & $15-135$ \\
During Lockdown (DL) & $<0.1-0.2$ & $<0.1$ & $1-12$ & $<0.1$ & $5-60$ & $10-50$ \\
After Lockdown (AL) & $0.1-0.6$ & $<0.1-0.1$ & $4-16$ & $<0.1$ & $10-110$ & $10-90$ \\
\hline
\end{tabular}

Table 4. Satellite data for mean air quality status of Port Harcourt city after lockdown.

\begin{tabular}{|c|c|c|c|c|c|c|}
\hline \multirow{2}{*}{ Date } & \multicolumn{6}{|c|}{ Air Quality Parameters $\left(\mu \mathrm{g} / \mathrm{m}^{3}\right)$} \\
\hline & $\mathrm{SO}_{2}$ & $\mathrm{NO}_{2}$ & $\mathrm{CO}$ & $\mathrm{O}_{3}$ & $\mathrm{PM}_{2.5}$ & $\mathrm{PM}_{10}$ \\
\hline \multicolumn{7}{|l|}{$15 / 7 / 2020$} \\
\hline Morning & 1 & 8 & 389 & 12 & 34 & 51 \\
\hline Afternoon & 1 & 2 & 251 & 12 & 38 & 50 \\
\hline Night & 2 & 18 & 699 & 25 & 23 & 48 \\
\hline \multicolumn{7}{|l|}{$16 / 7 / 2020$} \\
\hline Morning & 1 & 4 & 401 & 10 & 26 & 52 \\
\hline Afternoon & 1 & 2 & 218 & 74 & 29 & 59 \\
\hline Night & 1 & 13 & 527 & 11 & 20 & 56 \\
\hline \multicolumn{7}{|l|}{$17 / 7 / 2020$} \\
\hline Morning & 1 & 1 & 550 & 7 & 19 & 56 \\
\hline Afternoon & 1 & 1 & 229 & 68 & 22 & 51 \\
\hline Night & 1 & 11 & 275 & 27 & 15 & 45 \\
\hline
\end{tabular}

\begin{tabular}{|c|c|}
\hline $\begin{array}{l}\text { Good } \\
(0-50)\end{array}$ & None \\
\hline $\begin{array}{l}\text { Moderate } \\
(51-100)\end{array}$ & $\begin{array}{l}\text { Usually sensitive people should consider reducing } \\
\text { prolonged or heavy outdoor exertion. }\end{array}$ \\
\hline $\begin{array}{l}\text { Unhealthy } \\
\text { for } \\
\text { Sensitive } \\
\text { Groups } \\
(101-150)\end{array}$ & $\begin{array}{l}\text { The following groups should reduce prolonged or heavy } \\
\text { outdoor exertion: } \\
\text { - People with lung disease, such as asthma } \\
\text { - Children and older adults } \\
\text { - People who are active outdoors }\end{array}$ \\
\hline $\begin{array}{l}\text { Unhealthy } \\
(151-200)\end{array}$ & $\begin{array}{l}\text { The following groups should avoid prolonged or heavy } \\
\text { outdoor exertion: } \\
\text { - People with lung disease, such as asthma } \\
\text { - Children and older adults } \\
\text { - People who are active outdoors } \\
\text { Everyone else should limit prolonged outdoor exertion. }\end{array}$ \\
\hline $\begin{array}{c}\text { Very } \\
\text { Unhealthy } \\
(201-300)\end{array}$ & $\begin{array}{l}\text { The following groups should avoid all outdoor exertion: } \\
\text { - People with lung disease, such as asthma } \\
\text { - Children and older adults } \\
\text { - People who are active outdoors } \\
\text { Everyone else should limit prolonged outdoor exertion. }\end{array}$ \\
\hline
\end{tabular}

Figure 2. AQI score and corresponding public health precautions for residents (US EPA, 2014). 
and the possible implications on exposed inhabitants.

Results showed that ambient concentration values for particulates of sizes $\mathrm{PM}_{2.5}$ and $\mathrm{PM}_{10} \mathrm{BL}, \mathrm{DL}$ and $\mathrm{AL}$ ranged from $15-140 \mu \mathrm{g} / \mathrm{m}^{3}, 5-60 \mu \mathrm{g} / \mathrm{m}^{3}$ and $10-110 \mu \mathrm{g} / \mathrm{m}^{3}$ respectively (Table 3 ). The highest, medium and lowest domains of particulates concentrations before lockdown were at stations 1, 3, 5, 8 and 9; stations 2, 6, 7 and 10; and station 4 respectively (Table 2). During lockdown the lowest and highest domains of ambient particulates concentrations were stations 6 and 9 respectively with ranges between $5-60 \mu \mathrm{g} / \mathrm{m}^{3}$ across all the stations. However, after lockdown, there was a rise in particulates concentrations with range from $10-110 \mu \mathrm{g} / \mathrm{m}^{3}$ (Table 3). The highest ambient particulates concentrations were observed during these periods were at stations 8 and 9 while station 6 had the lowest ambient mean value indicating a domain of low start of economic and anthropogenic activities after lockdown. For other criterial pollutants such as $\mathrm{SO}_{2}$, NOS and $\mathrm{CO}$, ambient concentrations were higher before and after lockdowns with the various ranges as shown on Table 3. It is shown from Table 1 that stations $1-3,5-6,8-10$ recorded higher ambient mean $\mathrm{CO}$ values while station 7 recorded the lowest mean $\mathrm{CO}$ emitted domain (Table 2). After lockdown, stations 3, 9 and 10 showed an increase in mean $\mathrm{CO}$ ambient levels which indicate the resumption of anthropogenic activities. Mean satellite data as shown on Table 4 revealed a minimal to moderate air quality tropospheric status of Port Harcourt city after lockdown for the stated dates.

The air quality index (AQI) analysis as displayed on Table 2, showed that the ambient air quality status of Port Harcourt boundary layer was hazardous throughout all the stations before lockdown and these ranged from 331 - 593. Stations 1, 3, 4, 7, 9 and 10 were among the highest hazardous AQI domains. Unhealthy to very unhealthy AQI status was observed during lockdown with AQI range from 140 - 234 (Table 2). Stations 4 - 8 maintained unhealthy status for sensitive groups during this period. Very unhealthy AQI status dominated most of the stations after lockdown with stations 7, 9 and 10 assuming hazardous status. This indicated the rapid deteriorating effects of Port Harcourt air quality status after the period of lockdown. All through shutdown of activities, the air quality upgraded to unhealthy status, with an average reduction AQI of 261.7 points (Table 5). However, an average increase of 100.7 points, resulting to very unhealthy air status for residents after lockdown was observed.

Table 5. Average air quality index of Port Harcourt before, during and after COVID-19 pandemic lockdown.

\begin{tabular}{ccccc}
\hline Time & AQI & $\begin{array}{c}\text { Colour Code/ } \\
\text { Indicator }\end{array}$ & $\begin{array}{c}\text { Lockdown Effect (difference } \\
\text { between BL \& DL) }\end{array}$ & $\begin{array}{c}\text { Post-Lockdown Effect } \\
\text { (difference between DL \& AL) }\end{array}$ \\
\hline BL & 429.1 & Hazardous & & 100.7 \\
DL & 167.4 & Unhealthy & 261.7 & \\
AL & 268.1 & Very Unhealthy & & \\
\hline
\end{tabular}




\section{Discussion}

Over the years, Port Harcourt metropolis and some other cities in Nigeria have been experiencing high ambient air pollution levels and high health burdens, especially respiratory diseases and deaths associated with poor air quality (Fienemika et al., 2018; RSMENV, 2019). An assessment of air quality and means of improvement in the area has both local and international relevance. Providentially, the lockdown measures across most cities of the world have brought opportunity to account for emissions impact on the health of the society. Therefore, the outcome of this study may help to review how far anthropogenic activities are responsible for poor air quality and the resultant health burdens on the city. It could also help validate lockdown as a periodic novel environmental strategy for restoring the environment and provide sustainable, air pollution free and inhabitable ecosystem to urban people. It was disclosed by Fuwaper et al. (2020) that the most substantial impact of the lockdown period in Port Harcourt was during the early phase in March 2020, where about $21.9 \%$ and $37.3 \%$ reduction in $\mathrm{NO}_{2}$ and $\mathrm{SO}_{2}$ ambient air concentrations. It was also disclosed that a $1.1 \%$ and $215 \%$ decrease was observed during the next month. It should be emphasized that while the effect of the lockdown slightly lessened ambient air quality due to the key reductions in air emissions bearing anthropogenic activities within the urban areas, the operations of illegal refineries that take place in the rural domains immediately outside the boundaries of Port Harcourt metropolis subsisted. These differences in operational anthropogenic activities both in the urban and rural domains are due to the dissimilar intensities of lockdown enforcement (Fuwaper et al., 2020).

COVID-19 pandemic on one hand threatened the health of people globally, and on the other was an environment restoring factor (Paital, 2020). This prompted the global concern and attention to analysing air quality status of cities in the course of the pandemic. Across most cities of the world, temporary reduction in emission levels, especially criteria pollutants and improvement in air quality have been documented amidst industrial shutdown period and city lockdown (Jain \& Sharma, 2020; Bao \& Zhang, 2020). There are quit a handful of studies concerning changes in air quality during the lockdown amidst COVID-19 pandemic, hence the result of this study specifically related to Port Harcourt is not isolated from others as improvement in air quality due to lockdown of cities is also apparent all over the globe.

Port Harcourt metropolis is a petroleum industry driven city and have been recognized for poor ambient air quality. Result from this study showed that the ambient air quality of Port Harcourt was hazardous for breathing before lockdown. While during shutdown of activities, the air quality improved to unhealthy status, with an average reduction of AQI of 261.7 points. However, an average increase by 100.7 points, resulting to very unhealthy breathing air status for residents after lockdown was observed (see Table 4). Also, decrease in levels of the criteria air pollutants was observed (see Table 2). Like other studies by 
Yuri et al. (2020) the impact of the short-term lockdown on the air quality of Port Harcourt was substantial, meaning that all residents could have inhaled somewhat better air, except for sensitive groups (US EPA, 2014). However, upon resumption of activities and movement of people in the city after the lockdown, the ambient air quality deteriorated than it was during the lockdown.

Irrespective of the general improvement in air quality (decrease in AQI) seen during lockdown, levels of pollution and air quality differed across the city. During lockdown, sampled areas such as Eneka, Water Lines, Elekahia Stadium road, Sharks stadium axis and NNPC Mega Filling station in Port Harcourt old township recorded air quality status (AQI of below 150) fairly acceptable for breathing of residents, except for sensitive groups (US EPA, 2014). However, despite the lockdown areas such as Eleme Junction Fly-over, Rukpokwu Junction, Rumukrushi by Tank and Rumuola by Fly-over recorded AQI score of over 150 and above in the lockdown period, which is very unhealthy for all residents and worst for sensitive groups (US EPA, 2014). The variance in ambient pollution levels could result from high saturation of pollutants in the atmosphere, proximity to commercial and high vehicular and industrial activities, proximity to coastal areas where artisanal refining takes place and gas flaring by oil multinationals, as well as dispersion and emission dynamics premised on wind direction and other weather variables (Ede \& Edokpa, 2017; Yakubu et al., 2017; Asumadu et al., 2020).

\section{Conclusion and Recommendations}

The study showed that ambient air quality of Port Harcourt has long been inundated with pollutants known to be hazardous to human health. Though air quality was observed to have slightly improved during the lockdown, however the drop in pollution levels could not result to acceptable good air quality (0 - 50) AQI due to persistent and long term saturation of pollution levels. Except for sensitive groups who remained at risk of exposure irrespective of the slight decrease in pollution levels; generally, Port Harcourt residents are likely to have experienced more environmentally friendly boundary layer atmosphere during the lockdown periods as reduction in ambient air pollution increases populations' life expectancy by over a year. Good $(0-50)$ was not recorded across the sampled locations before, during and after the lockdown periods. Perhaps long and extended shutdown could have more beneficial effects to both sensitive groups and the entire populations. Establishing continuing and routine air quality measurements stations and the communication of daily air quality to residents could likely control air pollution on full resumption of economic activities. This is to ensure that the population, especially the sensitive groups and the more vulnerable target population are protected from severe public health complications. The non-pharmaceutical measures such as shutdown of industrial activities instituted by governments of most nations in curtailing the surge of coronavirus pandemic could likely be an environmental model for mitigating air 
pollution and its associated health burdens.

\section{Conflicts of Interest}

The authors declare no conflicts of interest regarding the publication of this paper.

\section{References}

Abowei, J. F. N., \& Tawari, C. C. (2012). Air Pollution in the Niger Delta Area of Nigeria. International Journal of Fisheries and Aquatic Sciences, 1, 94-117.

Anderson, R. M., Heesterbeek, H., Klinkenberg, D., \& Hollingsworth, T. D. (2020). How Will Country-Based Mitigation Measures Influence the Course of the COVID-19 Epidemic? Lancet, 395, 931-934. https://doi.org/10.1016/S0140-6736(20)30567-5

Arora, S., Deoli, K., \& Kumar, P. (2020). Science of the Total Environment Coronavirus Lockdown Helped the Environment to Bounce Back. Science of the Total Environment, 742, Article ID: 140573. https://doi.org/10.1016/j.scitotenv.2020.140573

Asumadu, S., Phebe, S., \& Owusu, A. (2020). Global Assessment of Environment, Health and Economic Impact of the Novel Coronavirus (COVID-19). Environment, Development and Sustainability. https://doi.org/10.1007/s10668-020-00801-2

Augustine, C. (2012). Impact of Air Pollution on the Environment in Port Harcourt, Nigeria Synthesis and Characterization of Sulphide/Oxide Core-Shell Thin Films Using Chemical Bath Deposition Method View Project.

Bao, R., \& Zhang, A. (2020). Science of the Total Environment Does Lockdown Reduce Air Pollution? Evidence from 44 Cities in Northern China. Science of the Total Environment, 731, Article ID: 139052. https://doi.org/10.1016/j.scitotenv.2020.139052

Broekstra, N., Luck, A., \& Gordeljevic, V. (2019). Healthy Air, Healthier Children. Health and Environment Alliance (HEAL) Report in 50 Schools across the EU Monitor Air Quality Berlin, London, Madrid, Paris, Sofia, Warsaw. Brussels: Health and Environment Alliance.

Chen, D., Liu, X., Lang, J., Zhou, Y., Wei, L., Wang, X., \& Guo, X. (2017). Estimating the Contribution of Regional Transport to $\mathrm{PM}_{2.5}$ Air Pollution in a Rural Area on the North China Plain. Science of the Total Environment, 583, 280-291.

https://doi.org/10.1016/j.scitotenv.2017.01.066

Cristina, M., Abbà, A., Bertanza, G., Pedrazzani, R., Ricciardi, P., \& Carnevale, M. (2020). Lockdown for CoViD-2019 in Milan: What Are the Effects on Air Quality? Science of the Total Environment, 732, Article ID: 139280. https://doi.org/10.1016/j.scitotenv.2020.139280

Ede, P. N., \& Edokpa, D. O. (2017). Satellite Determination of Particulate Load over Port Harcourt during Black Soot Incidents. Journal of Atmospheric Pollution, 5, 55-61.

Edokpa, D. O., \& Ede, P. N. (2019). Preliminary Air Quality Index Estimates of Particulates Concentration in Port Harcourt during Soot Incidents. International Journal of Innovative Studies in Sciences and Engineering Technology, 5, 25-29.

Fienemika, A. E., In, O., \& Best, O. (2018). Prevalence of Acute Respiratory Infections among Children Under-Five Years old in A Hospital in Port Harcourt, Nigeria: A Two Year Follow-Up Study. Journal of Respiratory Medicine, 2, 1-6.

Fu, S. H., \& Gu, Y. Z. (2017). Highway Toll and Air Pollution: Evidence from Chinese Cities. Journal of Environmental Economics \& Management, 83, 32-49. https://doi.org/10.1016/j.jeem.2016.11.007 
Fuwaper, I. A., Okpalaonwuka, C. T., \& Ogunjo, S. T. (2020). Impact of COVID-19 Pandemic Lockdown on Distribution of Inorganic Pollutants in Selected Cities of Nigeria. Air Quality, Atmosphere \& Health, 14, 149-155. https://doi.org/10.1007/s11869-020-00921-8

Gatto, M., Bertuzzo, E., Mari, L., Miccoli, S., Carraro, L., Casagrandi, R., Rinaldo, A., (2020). Spread and Dynamics of the COVID-19 Epidemic in Italy: Effects of Emergency Containment Measures. Proceedings of the National Academy of Sciences of the United States of America, 17, 10484-10491. https://doi.org/10.1073/pnas.2004978117

Gautam, S. (2020). COVID-19: Air Pollution Remains Low as People Stay at Home. Air Quality, Atmosphere \& Health, 13, 853-857. https://doi.org/10.1007/s11869-020-00842-6

Gourinchas, P.-O. (2020). Flattening the Pandemic and Recession Curves. In R. Baldwin, \& B. Weder di Mauro (Eds.), Mitigating the COVID Economic Crisis: Act Fast and Do Whatever It Takes (pp. 31-39). London: Centre for Economic Policy Research Press.

Guo, H., Kota, S. H., Chen, K., Sahu, S. K., Hu, J., Ying, Q. et al. (2018). Source Contributions and Potential Reductions to Health Effects of Particulate Matter in India. Atmospheric Chemistry and Physics, 18, 15219-15229.

https://doi.org/10.5194/acp-18-15219-2018

Jain, S., \& Sharma, T. (2020). Social and Travel Lockdown Impact Considering Coronavirus Disease (COVID-19) on Air Quality in Megacities of India: Present Benefits, Future Challenges and Way Forward. Aerosol and Air Quality Research, 20, 1222-1236. https://doi.org/10.4209/aaqr.2020.04.0171

Kanee, R. B., Adeyemi, A., Edokpa, D. O., \& Ede, P. N. (2020a). Particulate Matter-Based Air Quality Index Estimate for Abuja, Nigeria: Implications for Health. Journal of Geoscience and Environment Protection, 8, 313-321.

https://doi.org/10.4236/gep.2020.85019

Kanee, Rogers B., Adeyemi, W. J., N. Ede, P., Gobo, Ak. E., Maduka, O., Ojimah, C. et al. (2020b). Airborne Particulate Matter Pollution-Knowledge, Perception and Breathing Experiences of Port Harcourt Residents during COVID-19 Pandemic Shutdown. Sustainability in Environment, 5, 28. https://doi.org/10.22158/se.v5n3p28

Ladan, S. I. (2013). Examining Air Pollution and Control Measures in Urban Centers of Nigeria. International Journal of Environmental Engineering and Management, 4, 621-628.

Maduka, O., \& Tobin-West, C. (2017). Is Living in a Gas-Flaring Host Community Associated with Being Hypertensive? Evidence from the Niger Delta Region of Nigeria. BMJ Global Health, 2, e000413. http://dx.doi.org/10.1136/bmjgh-2017-000413

Mahato, S., Pal, S., \& Ghosh, K. G. (2020). Science of the Total Environment Effect of Lockdown Amid COVID-19 Pandemic on Air Quality of the Megacity Delhi, India. Science of the Total Environment, 730, Article ID: 139086. https://doi.org/10.1016/j.scitotenv.2020.139086

Mudu, P., Terracini, B., \& Martuzzi, M. (2014). Human Health in Areas with Industrial Contamination.

http://www.euro.who.int/_data/assets/pdf_file/0006/264813/Human-Health-in-Areaswith-Industrial-Contamination-Eng.pdf

Oliveira, M., Slezakova, K., Delerue-Matos, C., Pereira, M. C., \& Morais, S. (2019). Children Environmental Exposure to Particulate Matter and Polycyclic Aromatic Hydrocarbons and Biomonitoring in School Environments: A Review on Indoor and Outdoor Exposure Levels, Major Sources and Health Impacts. Environment International, 124, 180-204. https://doi.org/10.1016/j.envint.2018.12.052 
Paital, B. (2020). Science of the Total Environment Nurture to Nature via COVID-19, a Self-Regenerating Environmental Strategy of Environment in Global Context. Science of the Total Environment, 729, Article ID: 139088.

https://doi.org/10.1016/j.scitotenv.2020.139088

Rivers State Ministry of Environment (RSMENV) (2019). A Study of Airborne Particulate "Black Soot" in Port Harcourt and Its Environs. Port Harcourt: Government of Rivers State.

Taiwo, A. M. (2016). Particulate Matter Pollution in Nigeria: A Review. Proceedings of the 14th International Conference on Environmental Science and Technology, Rhodes, 3-5 September 2015. https://cest2015.gnest.org/papers/cest2015_00342_poster_paper.pdf

Tobías, A. (2020). Evaluation of the Lockdowns for the SARS-CoV-2 Epidemic in Italy and Spain after One Month Follow Up. Science of the Total Environment, 725, Article ID: 138539. https://doi.org/10.1016/j.scitotenv.2020.138539

United Nations Educational, Scientific and Cultural Organization (UNESCO) (2020). COVID-19 Educational Disruption and Response.

https://www.sdg4education2030.org/covid-19-educational-disruption-and-response-m arch-2020

US EPA (United States Environmental Protection Agency) (2014). Air Quality Index: A Guide to Air Quality and Your Health (pp. 1-8). EPA-456/F-14-002. Triangle Park, NC: United States EPA, Office of Air Quality Planning and Standards Outreach and Information Division Research.

Wang, P., Chen, K., Zhu, S., Wang, P., \& Zhang, H. (2020). Severe Air Pollution Events Not Avoided by Reduced Anthropogenic Activities during COVID-19 Outbreak. Resources, Conservation and Recycling, 158, Article ID: 104814. https://doi.org/10.1016/j.resconrec.2020.104814

World Health Organization, WHO (2020). Coronavirus Disease (COVID-19) Weekly Epidemiological Update and Weekly Operational Update.

https://www.who.int/emergencies/diseases/novel-coronavirus-2019/situation-reports/

Yakubu, H. O. (2017). Particle (Soot) Pollution in Port Harcourt Rivers State, Nigeria-Double Air Pollution Burden? Understanding and Tackling Potential Environmental Public Health Impacts. Environments, 5, 2.

https://doi.org/10.3390/environments5010002

Yuri, L., Nakada, K., \& Custodio, R. (2020). Science of the Total Environment COVID-19 pandemic: Impacts on the Air Quality during the Partial Lockdown in São Paulo State, Brazil. Science of the Total Environment, 730, Article ID: 139087. https://doi.org/10.1016/j.scitotenv.2020.139087

Zhou, F., Yu, T., Du, R., Fan, G., Liu, Y., Liu, Z., et al. (2020). Clinical Course and Risk Factors for Mortality of Adult Inpatients with COVID-19 in Wuhan, China: A Retrospective Cohort Study. Lancet, 395, 1054-1062.

https://doi.org/10.1016/S0140-6736(20)30566-3 